\title{
The prognostic impact of tumor budding in lung squamous cell carcinoma
}

\author{
Akciğer skuamöz hücreli karsinomlarda tümör tomurcuklanmasının \\ prognostik etkisi
}

\author{
Merih Tepeoğlu \\ Başkent Üniversitesi Tıp Fakültesi, Patoloji Ana Bilim Dalı, Ankara \\ Dergiye Ulaşma Tarihi:10.06.2019 Dergiye Kabul Tarihi:21.06.2019 Doi: 10.5505/aot.2019.76768
}

\section{ÖZET}

GíRiŞ ve AMAÇ: Akciğer skuamöz hücreli karsinomlarda ( $\mathrm{SCC}$ ) prognozu belirlemeye yönelik olarak kabul edilmiş bir histolojik parametre bulunmamaktadır. Ancak son yıllarda tümör tomurcuklanmasının bu tümörlerin prognozu üzerinde etkili olabileceği yönünde çalışmalar mevcuttur. Bizim bu çalışmadaki amacımız da, akciğer SCC'da tümör tomurcuklanma oranını belirlemek ve bu histolojik özelliğin prognostik faktörler ile bağlantısını ortaya koymaktır.

YÖNTEM ve GEREÇLER: Çalışmaya 2011 ile 2016 tarihleri arasında Başkent Üniversitesi Patoloji Anabilim Dalında SCC tanısı alan 36 akciğer rezeksiyon olgusu dahil edildi. Olgulara ait tüm Hematoksilen-eozin boyalı preparatlar değerlendirildi. Büyük tümör adalarından dallanarak, komsu parankime doğru tomurcuklanan ve 5 hücreden az tümör hücresi içeren tümör adaları tümör tomurcuklanması olarak değerlendirildi ve en çok tomurcuklanma aktivitesi olan alanlar sayılarak 1 büyük büyütme alanındaki toplam tümör tomurcuklanma sayıs1 (TTS) belirlendi.

BULGULAR: Yapılan histomorfolojik değerlendirmede, tüm hastalarda tümör tomurcuklanması saptanmış olup, 1 büyük büyütme alanında (BBA) saptanan ortalama TTS 5,36 $\pm 3,27$ 'dir. Olguların 13 tanesinde $(\% 36,1)$ TTS 5 'in altında, 23 tanesinde ise (\%63,9) 5 ve 5 'in üstündedir. TTS ile pT evresi $(\mathrm{p}=0,005)$, lenf nodu metastaz varlığ $1(p=0,032)$, uzak organ metastaz gelişimi $(p=0,05)$ ve TNM evresi $(p=0,003)$ arasında istatistiksel olarak

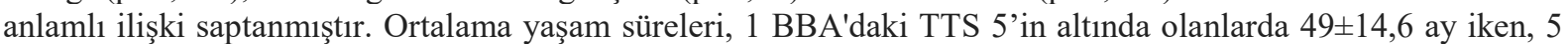
ve 5 'in üstünde olanlarda $30,1 \pm 17,7$ aydır $(\mathrm{p}=0,006)$.

TARTIŞMA ve SONUÇ: Çalışma sonucunda tümör tomurcuklanması ile pT evresi, TNM evresi, lenf nodu metastaz varlığı, metastaz gelişimi ve hastaların ortalama yaşam süreleri arasında anlamlı ilişki saptanmış olup, tümör tomurcuklanmasının kötü prognoz ile ilişkili olduğu ortaya konmuştur. Bu bulgu akciğer SCC derecelendirmede tümör tomurcuklanmasının histolojik bir parametre olarak kullanılabileceğini düşündürmektedir.

Anahtar Kelimeler: Akciğer, skuamöz hücreli karsinom, tümör tomurcuklanması

\begin{abstract}
INTRODUCTION: For lung squamous cell carcinoma (SCC), there is no histological parameter that have been universally accepted as a prognostic factor. However in recent years, tumor budding (TB) has been recognized as a prognostic factor. In this study, we investigated the ratio of TB in lung SCC and its influence on prognosis.

METHODS: Our study consisted of 36 resected lung SCC, diagnosed at the Baskent University, Department of Pathology, between 2011 and 2016. All haematoxylin and eosin-stained slides were reviewed. TB was defined as small tumor nests composed of less than 5 tumour cells that are branching from big tumor islands to the adjacent paranchyma. They were counted in 1 high-power fields (HPF) in hot spot areas. RESULTS: In histomorphological evaluation, TB was observed in all patients with the mean number of $5,36 \pm 3,27$ in $1 \mathrm{HPF}$. TB was $<5 / 1 \mathrm{HPF}$ in 13 cases $(36.1 \%)$ and $\geq 5 / 1 \mathrm{HPF}$ in 23 cases (63.9\%). The significant correlation was detected between TB and $\mathrm{pT}$ stage $(\mathrm{p}=0.005)$, lymph node metastasis $(\mathrm{p}=0,032)$, metastasis $(\mathrm{p}=0,05)$ and TNM stage $(\mathrm{p}=0,003)$. Patients with $<5$ budding $/ 1$ HPF had a mean overall survival of $49 \pm 14,6$ months, compared with $30,1 \pm 17,7$ months for those patients whose tumors had $\geq 5$ budding ( $\mathrm{p}=0,006$ ).

DISCUSSION AND CONCLUSION: In conclusion, the significant association was detected between TB and pT stage, TNM stage, lymph node metastasis/metastasis and overall survival. Hence, this study demonstrated that TB is an important predictor of poor prognosis in patients with SCC and it can be used as an histologic parameter in grading of lung SCC.

Keywords: Lung, squamous cell carcinoma, tumor budding
\end{abstract}




\section{GİRIŞ}

Akciğer kanseri tüm dünyada kansere bağlı ölümlerde ilk sırada yer almaktadır (1-7). Son y1llarda tedavi yöntemlerindeki gelişmelere karşın akciğer kanserinin hala prognozu oldukça kötü olup, rekürrens oranlar1 \%15-30, 5 yıllık sağ kalım oranı ise \%60-70 civarındadır (4-7). Akciğer kanserlerinin büyük kısmını küçük hücreli dışı akciğer karsinomları oluşturmaktadır. Skuamöz hücreli karsinomlar (SCC) da, küçük hücreli dış1 akciğer karsinomlarının yaklaşık olarak \%2030'nu kapsamaktadır (1-6). 2015 Dünya Sağlık Örgütü (WHO) akciğer kanser sinıflamasında, skuamöz hücreli karsinomlar morfolojik olarak keratinize, non-keratinize ve bazaloid subtiplere ayrılmıştır (1). Ancak bu subtiplerin prognostik veya klinik önemi olup olmadığı kesin olarak bilinmemektedir. Bu nedenle son y1llarda akciğer skuamöz hücreli karsinomlarda prognozu belirlemeye yönelik yeni histopatolojik özellikler üzerinde çalışılmaktadır. Tümör tomurcuklanma oranı da son zamanlarda akciğer SCC'ler üzerinde en çok çalışılan histopatolojik parametrelerden biridir. Biz de çalışmamız da akciğer skuamöz hücreli karsinomlarda tümör tomurcuklanma oranını belirlemek ve bu histolojik özelliğin prognostik etkisini ortaya koymayı amaçladık.

\section{MATERYAL VE METOT}

Ocak 2011 ile Mayıs 2016 tarihleri arasında Başkent Üniversitesi Patoloji Anabilim Dalında skuamöz hücreli karsinom tanısı alan 36 akciğer rezeksiyon olgusu çalışmaya dahil edildi. Çalışma için üniversiteden etik kurul onayı alınd. Olgulara ait Hematoksilen-eozin boyalı preparatlar değerlendirilerek, tümör tomurcuklanma sayıları belirlendi. Tümör tomurcuklanması, büyük tümör adalarından dallanarak, komşu parankime doğru tomurcuklanan ve 5 hücreden daha az tümör hücresi içeren küçük tümör adaları olarak kabul edildi (4,8-10). En çok tomurcuklanma aktivitesi olan alanlar sayıldı ve 1 büyük büyütme alanındaki (x200,0.55 $\mathrm{mm}$ ) toplam tümör tomurcuklanma sayısı belirlendi (4-10). Buna göre tümörler, 5'in altında tümör tomurcuklanması içeren ve 5 ve 5 'in üstünde tümör tomurcuklanması içerenler olarak 2 gruba ayrıldı. Olguların klinik ve prognostik takip bulguları kaydedildi ve tümör tomurcuklanması ile klinik parametreler arasındaki ilişki araştırıldı.

$$
\text { Verilerin }
$$

istatistiksel

değerlendirilmesinde SPSS 10.0 paket programı kullanıldı. Elde edilen sonuçlar ortalama \pm standart sapma olarak ifade edildi. Hastaların ortalama sağ kalım süreleri KaplanMeier yöntemi ile değerlendirildi. Gruplar arasında farklılık olup olmadığı Mann-Whitney U testi ile değerlendirildi. Anlamlılık düzeyi olarak $\mathrm{p}<0,05$ kabul edildi.

\section{BULGULAR}

Toplam 36 akciğer rezeksiyon olgusunun 34'ü (\%94.4) erkek, 2'si (\%5.6) kadındır. Ortalama yaş $65.13 \pm 8.2$ 'dir. Hastaların ortalama takip süreleri 36 aydır. Hastaların tamamında sigara içme hikayesi mevcuttur. Morfolojik olarak olguların 12 tanesi (\%33.3) keratinize tip, 22 tanesi (\%61.1) non-keratinize tip ve 2 tanesi de (\%5.6) bazaloid tip SCC'dir. Hastalarm 12 tanesi (\%33.3) patolojik evre 1 (pT1) , 18 tanesi (\%50) patolojik evre 2 (pT2) ve 6 tanesi de (\%16.7) patolojik evre 3'dür (pT3). Klinik evrelere baktığımızda ise, 15 hasta $(\% 41.7)$ Evre 1, 19 hasta (\%52.7) Evre 2 ve 2 hasta da (\%5.6) Evre 3'dür.

Olguların tümünde tümör tomurcuklanması saptanmıştır. 1 büyük büyütme alanında (1 BBA) saptanan ortalama tümör tomurcuklanma sayıs1 5.36 \pm 3.27 (114)'dir. Olguların 13 tanesinde (\%36.1) tümör tomurcuklanma sayıs1 (TTS) 1 BBA'da 5'in altında olup, 23 tanesinde (\%63.9) 1 BBA'daki TTS 5 ve 5 'in üstündedir (Figür 1). 1 BBA'daki TTS, keratinize tip SCC olgularının 7'sinde (\%58.3) 5'in altında, 5 'inde (\%41.7) 5 ve 5 'in üstündedir. Non-keratinize SCC'lerin ise 15 'inde $(\% 68.1)$ 5'in altında, 7'sinde (\%31.9) 5 ve 5 'in üstündedir. Bazaloid tip SCC'lerin ise 1'inde (\%50) 5 'in altında, 1 'inde (\%50) 5 ve 5 'in üzerindedir ( $\mathrm{p}>0.05)$.

1 BBA'daki TTS, pT1 evresinde olan hastaların 8'inde (\% 66.7) 5 'in altında olup, 4'ünde (\%33.3) 5 ve 5 'in üzerindedir. pT2 evresindeki hastaların 5 tanesinde (\%27.8) 5'in altında, 13 tanesinde ise $(\% 72.2) 5$ ve 5 'in üzerinde tümör tomurcuklanması saptanmış olup, pT3 evresindeki hastaların ise hepsinde TTS, 5 ve 5 'in üzerindedir $(\mathrm{p}=0.005) .1$ BBA'daki TTS, klinik evre 1 olan hastaların 10 tanesinde (\%66.7) 5 'in altında, 5 tanesinde (\%33.3) 5 ve 5 'in üstündedir. Evre 2 olan 
hastaların 3'ünde (15.8) TTS, 5'in altında olup, 16 tanesinde (\%84.2) 5 ve 5 'in üstündedir. Evre 3 olan hastaların ise hepsinde TTS 5 'in üstündedir $(\mathrm{p}=0.003)$

Olguların 22 tanesinde (\%61.1) vasküler invazyon izlenmemiş, 14 tanesinde (\%38.9) vasküler invazyon saptanmıştır. Vasküler invazyonu olmayan hastalarda, 1 BBA'daki TTS 7 olguda (31.8) 5'in altında, 15 olguda ise $(\% 68.2) 5$ ve 5 'in üstündedir. Vasküler invazyonu olan hastalarda ise, 6 tanesinde (42.9) 5'in altında, 8 tanesinde ise (\%57.1) 5 ve 5 'in üstünde tümör tomurcuklanması izlenmiştir $\quad(\mathrm{p}>0.05)$. Olguların 22 tanesinde (\%61.1) lenf nodu metastazı izlenmemiş, 14 tanesinde (\%38.9) ise lenf nodu metastazı saptanmıştır. Lenf nodu metastazı olmayan hastaların yarısında TTS 5 'in altında, yarısında ise 5 ve 5 'in üstündedir. Lenf nodu metastazı olan hastaların ise, 2'sinde (\%14.3) 5'in altında, 12'sinde ise $(\% 85.7) 5$ ve 5 'in üstünde tümör tomurcuklanması izlenmiştir $(\mathrm{p}=0.032)$. Takip sirasinda olguların 6 tanesinde (\%16.7) uzak organ metastazı saptanmıştır. Metastaz saptanan hastaların tümünde 1BBA'da 5 ve 5'in üzerinde tümör tomurcuklanmas1 saptanmış olup, metastaz olmayan hastaların 13'ünde (\%43.3) 5'in altında, 17 tanesinde $(\% 56.7)$ ise 5 ve 5 'in üzerinde tümör tomurcuklanması görülmüştür $\quad(\mathrm{p}=0.05)$. Hastaların klinikopatolojik bulguları ile tümör tomurcuklanması arasındaki istatistiksel ilişki Tablo 1'de gösterilmiştir.

Ortalama yaşam süresi,1 BBA'daki TTS 5'in altında olanlarda $49 \pm 14.6$ ay iken, 5 ve 5 'in üzerinde olanlarda $30.1 \pm 17.7$ ay'dır $(\mathrm{p}=0.006) . \quad 1$ ve 3.y1llardaki sağ kalım oranlarına bakıldığında ise, 1 BBA'daki TTS 5 'in altında olanlarda \%100, 5 ve 5 'in üzerinde olanlarda sirasiyla $\% 82$ ve $\% 69$ 'dir $(\mathrm{p}=0.032)$. Takip sonunda 7 hasta (\%19.4) ölmüş, 29 hasta (\%80.6) halen yaşamaktadır. Ölen hastaların tümünde 1 BBA'daki TTS 5 ve 5 'in üzerindedir. Yaşayan hastaların ise 13 tanesinde (\%44.8) TTS 5'in altında, 16 tanesinde ise $(\% 55.2) 5$ ve 5 'in üzerindedir $(\mathrm{p}=0.029)$

Tablo-1. Tümör tomurcuklanma sayısı (TTS) ile hastaların klinikopatolojik bulguları arasındaki ilişki

\begin{tabular}{|c|c|c|c|c|c|}
\hline \multirow{2}{*}{\multicolumn{2}{|c|}{$\begin{array}{c}\text { Klinikopatolojik } \\
\text { bulgular }\end{array}$}} & \multicolumn{2}{|c|}{ TTS } & \multirow{3}{*}{$\begin{array}{c}\text { Toplam } \\
\text { (n) } \\
\\
\\
2\end{array}$} & \multirow{4}{*}{$\begin{array}{r}\mathbf{p}^{*} \\
\\
0,78\end{array}$} \\
\hline & & $<5 / 1 \mathrm{BBA}$ & $\geq 5 / 1 \mathrm{BBA}$ & & \\
\hline \multirow[t]{2}{*}{ Cinsiyet } & Kadın & $1(\% 50)$ & $1(\% 50)$ & & \\
\hline & Erkek & $20(\% 58,8)$ & $14(\% 41,2)$ & 34 & \\
\hline \multirow{3}{*}{$\begin{array}{l}\text { Histoloji } \\
\text { k subtip }\end{array}$} & Keratinize & $7(\% 58.3)$ & $5(541.7)$ & 12 & \multirow[t]{3}{*}{0,63} \\
\hline & $\begin{array}{c}\text { Non- } \\
\text { keratinize }\end{array}$ & $15(\% 68,1)$ & $7(\% 31,9)$ & 22 & \\
\hline & Bazaloid & $1(\% 50)$ & $1(\% 50)$ & 2 & \\
\hline \multirow{3}{*}{$\begin{array}{c}\text { Patolojik } \\
\text { T evresi }\end{array}$} & $\mathrm{T} 1$ & $8(\% 66,7)$ & $4(\% 33,3)$ & 12 & \multirow[t]{3}{*}{0,005} \\
\hline & $\mathrm{T} 2$ & $5(\% 27,8)$ & $13(\% 72,2)$ & 18 & \\
\hline & T3 & 0 & $6(\% 100)$ & 6 & \\
\hline \multirow{3}{*}{$\begin{array}{c}\text { Klinik } \\
\text { evre }\end{array}$} & 1 & $10(\% 66,7)$ & $5(\% 33,3)$ & 15 & \multirow[t]{3}{*}{0,003} \\
\hline & 2 & $3(\% 15,8)$ & $16(\% 84,2)$ & 19 & \\
\hline & 3 & 0 & $2(\% 100)$ & 2 & \\
\hline \multirow{2}{*}{$\begin{array}{c}\begin{array}{c}\text { Lenf } \\
\text { nodu } \\
\text { metastazı }\end{array} \\
\end{array}$} & Yok & $11(\% 50)$ & $11(\% 50)$ & 22 & \multirow[t]{2}{*}{$\mathbf{0 , 0 3 2}$} \\
\hline & Var & $2(\% 14,3)$ & $12(\% 85,7)$ & 14 & \\
\hline \multirow{2}{*}{$\begin{array}{c}\text { Uzak } \\
\text { organ } \\
\text { metastazı }\end{array}$} & Yok & $13 \% 43,3)$ & $17(\% 56,7)$ & 30 & \multirow[t]{2}{*}{0,05} \\
\hline & Var & 0 & $6(\% 100)$ & 6 & \\
\hline \multirow{2}{*}{$\begin{array}{l}\text { Vasküler } \\
\text { invazyon }\end{array}$} & Yok & $7(\% 31,8)$ & $15(\% 68,2)$ & 22 & \multirow[t]{2}{*}{0,37} \\
\hline & Var & $6(\% 42,9)$ & $8(\% 34,8)$ & 14 & \\
\hline \multirow[t]{2}{*}{$\mathbf{E x}$} & Ex & 0 & $7(\% 100)$ & 7 & \multirow[t]{2}{*}{0,45} \\
\hline & Yaşıyor & $13(\% 44,8)$ & $16(\% 55,2)$ & 29 & \\
\hline Total & & $13(\% 36.1)$ & $23(\% 63.9)$ & 36 & \\
\hline
\end{tabular}
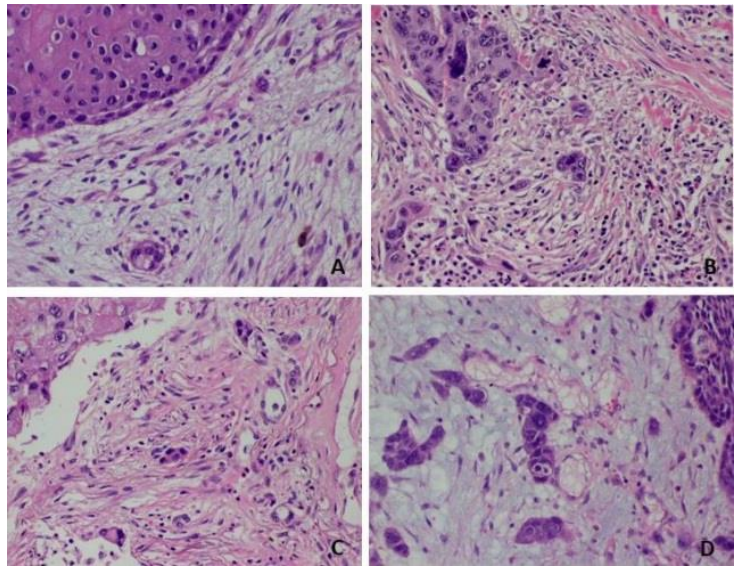

Figür 1: Histolojik kesitlerde $1 \mathrm{BBA}$ 'da 5'in altında tümör tomurcuklanması içeren olgular $(\mathrm{A}, \mathrm{B})$ ve 1 BBA'da 5'in üzerinde tümör tomurcuklanması içeren olgular $(\mathrm{C}, \mathrm{D})$ izleniyor (Hematoksilen-eozin, x200)

\section{TARTIŞMA}

Akciğer kanseri, tüm dünyada en sik görülen kanser olmasının yanısıra, her iki cinsiyet de en çok ölüme sebep olan kanser tipidir (1-7). Bunun en önemli sebebi hastaların tanı anında 
büyük oranda $(\% 70)$ ileri evrede olmasıdır. Akciğer kanser tiplerinin büyük kısmını küçük hücreli dışı akciğer karsinomları (KHDAK) oluşturmaktadır. KHDAK'larının için de en s1k görülen tümör tipleri ise skuamöz hücreli karsinom (SCC) ve adenokarsinomdur. (1-7). Adenokarsinomlar için 2011 yılında International Association for the study of Lung cancer (IASLC), American Thoracic Society (ATS) ve European Respiratory Society (ERS) grupları tarafindan belirlenen ve baskın histolojik paterne göre gruplanan bir grade'leme sistemi ortaya konmuştur (2). Skuamöz hücreli karsinomlar için ise, ortak kullanılan ve prognostik yansımaları net olarak bilinen bir grade'leme sistemi bulunmamaktadır. 2015 WHO siniflamasında, SCC, morfolojik olarak keratinizasyon ya da hücreler arası köprü/desmozom içeren veya morfolojik olarak undiferansiye bir küçük hücreli dışı akciğer kanseri olup, immünhistokimyasal olarak skuamöz farklılaşma gösteren malign epitelyal akciğer tümörü olarak tanımlanmıştır ve keratinize, non-keratinize ve bazaloid subtiplere ayrılmıştır (1). Ancak belirlenen bu subtiplerin prognostik önemi olup olmadiğ 1 bilinmemektedir. $\mathrm{Bu}$ nedenle de, son y1llarda akciğer SCC' lu hastaların prognozunu belirlemeye yönelik çeşitli histolojik parametreler üzerinde çalışılmaktadır. Tümör tomurcuklanması da, son zamanlarda akciğer SCC'da prognostik parametre olarak en çok araştırılan histolojik özelliklerden biridir.

Tümör tomurcuklanması ilk olarak kolorektal kanserlerin invazyon sinırında görülen tek tümör hücreleri ya da 5'in altında tümör hücresi içeren küçük tümör adaları olarak tanımlanmıştır (8). Tümör invazyon sınırında, tümör stromasında izlenen tümör tomurcuklanmasının epitelyal-mezenkimal bir etkileşim olduğu (8-12) ve kanser hücre migrasyonunu ve invazyonunu arttırdığ 1 düşünülmektedir (13). $\mathrm{Bu}$ nedenle de kolorektal kanserlerde izlenen tümör tomurcuklanmasının tümörün invazyon karakterini yansıttığ1 ve bağımsız bir kötü prognostik faktör olduğu düşünülmektedir $(10,11,14)$. Literatürde, kolorektal kanserlerde tümör tomurcuklanma sayısının kötü prognostik etkisi ile ilgili pek çok çalışma bulunmaktadır $(11,12,15,16)$. Bu çalışmalarda, tümör tomurcuklanması ile yüksek TNM evresi, yüksek grade, lenfovasküler invazyon varlığı, lenf nodu metastazı ve uzak organ metastazı arasında anlamlı prognostik ilişki saptanmıştır $(11,15,16)$.

Tümör tomurcuklanma sayısının hesaplanması ile ilgili literatürde pek çok farklı yöntem bulunmakla birlikte, en çok kabul gören yöntem Ueno ve arkadaşları tarafindan tanımlanan yöntemdir $(8,10,17,18)$. Buna göre, tümör tomurcuklanmas1, histolojik olarak tomurcuklanmanın en yoğun olduğu yerlerde ve mikroskopik olarak 20' lik büyütmede $(0.55$ $\mathrm{mm}$ ) sayılır (8). 1 veya 10 BBA'daki en yüksek sayıdaki toplam tümör tomurcuklanma sayısı belirlenir. Belirlenen TTS'na göre tümörler; hiç tümör tomurcuklanması içermeyenler, düşük tümör tomurcuklanması içerenler ve yüksek tümör tomurcuklanması içerenler olarak 3 gruba ayrilır $(3,5,9,14)$.

Kolorektal tümörlerdeki prognostik etkisi ortaya konduktan sonra, pek çok organ tümöründe de tümör tomurcuklanmasinın prognostik etkisi araştırılmaya başlanmıştır. Bunlar arasında üst gastrointestinal sistem, pankreas, meme, baş-boyun bölgesi (oral bölge, dil, larinks) yer almaktadır. (19-21). Son y1llarda tümör tomurcuklanmasının prognostik etkisinin sıklıkla araştırılmaya başlandığı bir diğer organ da akciğerdir.

Literatürde,

tümör tomurcuklanmasının akciğer SCC üzerindeki etkisini gösteren ilk çalışma Taira ve arkadaşları tarafından 2012 yılında yapılan bir çalışmadır (3). 217 SCC olgusundan oluşan bu çalışmada, Taira ve arkadaşları, tümör tomurcuklanması olan SCC olgularının ortalama yaşam sürelerinin, tümör tomurcuklanması olmayanlara göre daha düşük olduğunu saptamıştır. Ayrıca tümör tomurcuklanma varlığı ile yüksek patolojik evre, lenf nodu metastazı, vasküler invazyon ve lenfatik invazyon varlığ 1 arasında anlamlı istatistiksel ilişki olduğunu ortaya koymuşlardır (3). Taira'nın hemen arkasından Masuda ve arkadaşları da aynı yıl içerisinde, 103 akciğer SCC olgusu üzerinde yaptıkları ve tümör tomurcuklanmasını değerlendirdikleri çalışmayı yayınlamışlardır (5). Bu çalışmada, tümörler, tümör tomurcuklanması içermeyen (Grade 1), düşük tümör tomurcuklanma oranına sahip ( $<3 / 1 \mathrm{BBA}$, Grade 2) ve yüksek tümör tomurcuklanma oranına sahip ( $\geq 3 / 1$ BBA, Grade 3) olarak ayrılmıştır ve tümör tomurcuklanma varlığı ile lenf nodu metastazı ve lenfatik invazyon arasinda anlaml 
istatistiksel ilişki saptanmıştır. Ayrıca tümör tomurcuklanması olan hastalarda, tümör tomurcuklanması olmayanlara göre ortalama yaşam süreleri daha düşük bulunmuştur. Ancak tümör tomurcuklanma sayıları ile klinik parametreler arasinda istatistiksel olarak anlamlı ilişki saptanmamıştır (5). Sonuç olarak her iki çalışmada da, tümör tomurcuklanmasının, SCC' lu hastalarda lokal agresif büyümeyi işaret ettiği sonucuna varılmış ve hastanın lenf nodu durumunu göstermek için anlamlı bir gösterge olabileceği vurgulanmıștır $(3,5)$.

Kadota ve arkadaşları, 2014 yılında 485 akciğer SCC olgusu üzerinde yaptıkları çalışmada ise, tümör tomurcuklanmasının yanısıra, tek hücre invazyonu, nükleer boyut ve tümör ada boyutu gibi histolojik parametreleri de değerlendirerek, SCC'daki prognostik önemlerini araştırmışlardır (14). Tümör tomurcuklanma sayısinı hem 1, hem 10 BBA'da ayrı olarak değerlendirmişler ve tümörleri düşük ve yüksek TTS içerenler diye ayırmışlar ve sonuç olarak her iki değerlendirmede de, tümör tomurcuklanmasının kötü prognoz ile ilişkili olduğu sonucuna varmışlardır. Diğer histolojik parametrelerden de tek hücre invazyonu olanlar ve büyük nükleer boyuta sahip olan tümörlerin, tümör tomurcuklanması ile benzer şekilde düşük ortalama săg kalım oranları gösterdikleri sonucuna varmışlardır (14).

2015 yılında Gürel ve arkadaşları tarafindan yayınlanan çalışmada ise, 76 SCC olgusunda diferansiasyon, mitotik indeks, nekroz varlığı, tümör stroma oran1, stromal lenfositik infiltrasyon ve tümör tomurcuklanmasının prognostik önemi araştırılmıştır (4). Tümörler ilk önce tomurcuklanma içerip içermediklerine göre ayrılmışlardır. Daha sonra da 1 BBA'da 5'in altında tümör tomurcuklanması içerenler düşük tomurcuklanma indeksli tümörler, 5 ve 5 'in üstünde tümör tomurcuklanması içerenler ise yüksek tomurcuklanma indeksli tümörler olarak ikiye ayrılmıştır. Çalışma sonucunda, yüksek TTS olan hastalarda, daha yüksek oranda lokorejionel rekürrens saptanmış, ancak bu oran istatistiksel olarak anlaml bulunmamıştır. Çalışmada değerlendirilen diğer histolojik parametrelerden ise, mitotik indeks ve tümör nekrozu, SCC hastalarında prognozu belirlemede anlamlı bulunmuştur (4).
Akciğer SCC'daki tümör tomurcuklanması ile ilgili literatürde yapılmış en geniş serili çalışma Weichert ve arkadaşları tarafından 2016 yılında yapılan ve 541 hastadan oluşan çalışmadır (9). Bu çalışma sonucunda keratinizasyon, küçük hücre ada boyutu, yüksek stromal içerik ve yüksek tümör tomurcuklanması içeren tümörlerin daha kötü prognoza sahip oldukları gösterilmiştir. Hatta Weichert ve arkadaşları, bu histolojik parametreler içinde prognostik olarak en anlamlı bulunan tümör tomurcuklanması ve tümör hücre ada boyutunun birlikte değerlendirilerek ortak bir skor verilebileceği ve bu skorunda akciğer SCC'ları grade'lemede kullanılabileceğini ileri sürmüşlerdir (9). 2017 yılında Kadota ve arkadaşları ise, akciğer SCC'da tümör tomurcuklanması ve nükleer boyutun birlikte değerlendirilerek bir gradeleme sistemi kullanılabileceğini ve bu gradeleme'nin prognostik anlamı olduğunu öne sürmüşlerdir (22).

Tümör tomurcuklanması, literatürde akciğer adenokarsinomlarında da çalışılmıştır $(13,23)$. Yamaguchi ve arkadaşlarının 181 akciğer adenokarsinomunda yaptığı çalışmada, tümör tomurcuklanması ile lenf nodu metastazı, patolojik evre, vasküler invazyon, lenfatik invazyon ve plevral invazyon arasinda anlamlı prognostik ilişki saptanmıştır (13). Kadota ve arkadaşları da Yamaguchi ile benzer şekilde, akciğer adenokarsinomlarında tümör tomurcuklanmasının kötü prognostik faktör olduğunu ve hastaların ortalama yaşam süreleri ve rekürrens oranları ile doğrudan ilişkili olduğunu saptamışlardır (23). Sonuç olarak akciğer adenokarsinomlarında da, skuamöz hücreli karsinomlarda olduğu gibi tümör tomurcuklanması kötü prognostik parametredir $(13,23)$.

Biz de çalışmamızdaki tüm olgularda tümör tomurcuklanması saptadık ve literatür ile benzer şekilde, tümörleri 1 BBA'daki tümör tomurcuklanma sayılarına göre düşük $(<5 / 1$ BBA) ve yüksek ( $\geq 5 / 1$ BBA) TTS içeren tümörler olarak ayırdık $(4,19,20,21)$. Daha sonra TTS ile hastaların klinik ve prognostik parametreleri arasındaki ilişkiyi araştırdık. TTS ile cinsiyet, histolojik alt tip ve vasküler invazyon arasında anlamlı istatistiksel ilişki saptamamıs olup, pT evresi, TNM evresi, lenf nodu ve uzak organ metastaz varlıği ve hastaların ortalama să̆ kalım süreleri arasında 
istatistiksel olarak anlamlı ilişki saptadık. Buna göre, yüksek TTS'na sahip olan hastaların pT ve TNM evresinin daha yüksek olduğunu, bu hastaların daha yüksek oranda lenf nodu ve uzak organ metastazı gösterdiklerini ve daha kısa ortalama sağ kalım süresine sahip olduklarını saptadık. Sonuç olarak, çalışmamızda literatür ile benzer şekilde TTS'nın akciğer skuamöz hücreli karsinomlarda kötü prognostik faktör olduğu sonucuna vardık. $\mathrm{Bu}$ bulgu ile akciğer skuamöz hücreli karsinomları derecelendirmede tümör tomurcuklanmasının histolojik bir parametre olarak kullanılabileceği sonucuna ulaşılmıştır.

\section{Çıkar Çatışması: Yok}

\section{REFERANSLAR}

1. Travis W.D, Brambilla E, Burke A.P, Marx A, Nicholson A.G. Tumours of the lung. In WHO Classification of Tumours of the Lung, Pleura, Thymus and Heart (4th edition). Lyon 2015; 51-63

2. Travis WD, Brambilla E, Noguchi M, "et al", International Association for the study of Lung cancer/ American thoracic society/ European thoracic society /European respiratory society international multidisciplinary classification of lung adenocarcinoma. J Thorac Oncol 2011;6:244-285

3. Taira T, Ishii G, Nagai $K$, "et al", Characterization of the immunophenotype of the tumor budding and its prognostic implications in squamous cell carcinoma of the lung. Lung cancer 2012;76:423430

4. Gürel D, Ulukuş Ç, Karaçam V, "et al". The prognostic value of morphologic findings for lung squamous cell carcinoma patients. PathologyResearch and Practice 2016 (212):1-9

5. Masuda R, Kijima H, Imamura N, "et al". Tumor budding is a significant indicator of a poor prognosis in lung squamous cell carcinoma patients. Molecular Medicine Reports 2012;6:937943

6. Kinoshita T, Ohtsuka T, Hato $T$, "et al", Prognostic factors based on clinicopathological data among the patients with resected peripheral squamous cell carcinomas of the lung. Journal of Thoracic Oncology 2014; 9 (12) :1779-1787

7. Zhao Y, Shen H, Qiu C, “et al”. Invasion types are associated with poor prognosis in lung squamous carcinoma patients. Medicine 2015;94(43): 1-11

8. Ueno H, Murphy J, Jass JR, Mochizuki H, Talbot IC. Tumour 'budding' as an index to estimate the potential of agressiveness in rectal cancer. Histopathology 2002;40:127-132.

9. Weichert W, Kossakowski C, Harms A, "et al". Proposal of a prognostically relevant grading scheme for pulmonary squamous cell carcinoma. Eur Respir j 2016;47:938-946.

10. Hase K, C.Shatney, D.Johnson, M.Trollope, M.Viera. Prognostic value of tumor 'budding' in patients with colorectal cancer. Dis.Colon Rectum 36 (1993):627-635.

11. Lugli A (2), Kirsch R, Ajioka Y, "et al". Recommendations for reporting tumor budding in colorectal cancer based on the International Tumor budding consensus conference (ITBCC) 2016. Modern Pathology 2017;30:1299-1311

12. Koelzer VH, Zlobec I, Lugli A. Tumor budding in colorectal cancer-ready for diagnostic practice? Human Pathol 2015;47:4-19

13. Yamaguchi $Y$, Ishii G, Kojima $M$, "et al". Histopathological features of the tumor budding in adenocarcinoma of the lung:Tumor budding as an index to predict the potential aggressiveness. Journal of Thoracic Oncology 2010;5:1361-1368

14. Kadota K, Nitadori J, Woo K, "et al". Comprehensive Pathological analyses in lung squamous cell carcinoma. Single cell invasion, nuclear diameter, and tumor budding are independent prognostic factors for worse outcomes. Journal of Thoracic Oncology 2014;9:1126-1139

15. Mitrovic B, Schaeffer DF, Riddell RH, Kirsch R. Tumor budding in colorectal carcinoma:time to take notice. Modern Pathology 2012;25:1315-1325

16. Lugli A, Karamitopoulou E, Zlobec I. Tumor budding:a promising parameter in colorectal cancer. Br J Cancer 2012;106:1713-1717

17. Goldstein NS, Hart J. Histologic features associated with lymph node metastasis in stage $\mathrm{T} 1$ and superficial $\mathrm{T} 2$ rectal adenocarcinomas in abdominoperineal resection specimens. Identifying a subset of patients for whom treatment with adjuvant therapy or completion abdominoperineal resection should be considered after local excision. Am j Clin Pathol 1999; 111:51-58

18. Nakamura $T$, Mitomi $H$, Kanazawa $H$, Ohkura $Y$, Watanabe M. Tumor budding as an index to identify high-risk patients with stage II colon cancer. Dis Colon Rectum 2008;51:568-572.

19. Nakanishi Y, Ohara M, Doumen H, Kimura N, Ishidate $\mathrm{T}$, Kondo $\mathrm{S}$. Correlation between tumor budding and post-resection prognosis in patients with invasive squamous cell carcinoma of the thoracic esophagus. World J Surg 2011;35:349-356

20. Wang $C$, Huang $H$, Huang $Z$, "et al'. Tumor budding correlates with poor prognosis and epithelial-mesenchymal transition in tongue squamous cell carcinoma. J Oral Pathol Med 2011;40:545-551

21. Sarığlu S, Acara C, Akman FC, "et al". Tumor budding as a prognostic marker in laryngeal carcinoma. Pathol Res Practice 2010;206:88-92

22. Kadota $\mathrm{K}$, Miyai $Y$, Katsuki N, "et al'. A grading system combining tumor budding and nuclear diameter predicts prognosis in resected lung squamous cell carcinoma. Am J Surg Pathol 2017;41:750-760

23. Kadota K, Yeh YC, Villena-Vargas J, "et al". Tumor budding correlates with the protumor 1mmune microenvironment and is an independent prognostic factor for recurrence of stage I lung adenocarcinoma. Chest 2015;148:711-721 